\title{
Age-related alteration of vitamin D metabolism in response to low-phosphate diet in rats
}

\author{
Tsui-Shan Chau ${ }^{1} \dagger$, Wan-Ping Lai ${ }^{1} \dagger$, Pik-Yuen Cheung ${ }^{1}$, Murray J. Favus ${ }^{2}$ and Man-Sau Wong ${ }^{1} *$ \\ ${ }^{1}$ Central Laboratory of the Institute of Molecular Technology for Drug Discovery and Synthesis, Department of Applied Biology and \\ Chemical Technology, The Hong Kong Polytechnic University, Hung Hom, Kowloon, Hong Kong, PRC \\ ${ }^{2}$ Section of Endocrinology, Department of Medicine, The University of Chicago, Chicago, IL 60 637, USA
}

(Received 14 April 2004 - Revised 19 August 2004 - Accepted 12 October 2004)

\begin{abstract}
The responses of renal vitamin D metabolism to its major stimuli alter with age. Previous studies showed that the increase in circulating 1,25-dihydroxyvitamin $\mathrm{D}\left(1,25(\mathrm{OH})_{2} \mathrm{D}_{3}\right)$ as well as renal 25-hydroxyvitamin $\mathrm{D}_{3} 1-\alpha$ hydroxylase (1-OHase) activity in response to dietary Ca or $\mathrm{P}$ restriction reduced with age in rats. We hypothesized that the mechanism involved in increasing circulating $1,25(\mathrm{OH})_{2} \mathrm{D}_{3}$ in response to mineral deficiency alters with age. In the present study, we tested the hypothesis by studying the expression of genes involved in renal vitamin D metabolism (renal 1-OHase, 25-hydroxyvitamin D 24-hydroxylase (24-OHase) and vitamin D receptor (VDR)) in young (1-month-old) and adult (6-month-old) rats in response to low-phosphate diet (LPD). As expected, serum $1,25(\mathrm{OH})_{2} \mathrm{D}_{3}$ increased in both young and adult rats upon LPD treatment and the increase was much higher in younger rats. In young rats, LPD treatment decreased renal 24-OHase (days $1-7, P<0.01$ ) and increased renal 1-OHase mRNA expression (days $1-5, P<0.01$ ). LPD treatment failed to increase renal 1-OHase but did suppress 24-OHase mRNA expression $(P<0.01)$ within $7 \mathrm{~d}$ of LPD treatment in adult rats. Renal expression of VDR mRNA decreased with age $(P<0.001)$ and was suppressed by LPD treatment in both age groups $(P<0 \cdot 05)$. Feeding of adult rats with $10 \mathrm{~d}$ of LPD increased 1-OHase $(P<0.05)$ and suppressed 24-OHase $(P<0.001)$ as well as VDR $(P<0.05)$ mRNA expression. These results indicate that the increase in serum $1,25(\mathrm{OH})_{2} \mathrm{D}_{3}$ level in adult rats during short-term LPD treatment is likely to be mediated by a decrease in metabolic clearance via the down-regulation of both renal 24-OHase and VDR expression. The induction of renal 1-OHase mRNA expression in adult rats requires longer duration of LPD treatment than in younger rats.
\end{abstract}

25-Hydroxyvitamin $D_{3}$ 1- $\alpha$ hydroxylase: 25-Hydroxyvitamin $D_{3} 24$ hydroxylase: Vitamin $D$ receptor: Low-phosphate diet: Adult rats

1,25-Dihydroxyvitamin $\mathrm{D}_{3}\left(1,25(\mathrm{OH})_{2} \mathrm{D}_{3}\right)$, the active metabolite of vitamin $\mathrm{D}_{3}$, is the major regulator of intestinal $\mathrm{Ca}$ and $\mathrm{P}$ absorption. Serum $1,25(\mathrm{OH})_{2} \mathrm{D}_{3}$ level is under stringent control to meet the skeletal requirement of $\mathrm{Ca}$ and $\mathrm{P}$, such as during growth, pregnancy, lactation or when the dietary intake of Ca and $\mathrm{P}$ is low (Wilz et al. 1979; Favus \& Tembe, 1992). The major regulators of $1,25(\mathrm{OH})_{2} \mathrm{D}_{3}$ levels are parathyroid hormone (PTH; Garabedian et al. 1972), serum Ca and P (Hughes et al. 1975), growth hormone (Spanos et al. 1978), insulin-like growth factor I (Gray \& Garthwaite, 1985; Nesbitt \& Drezner, 1993; Condamine et al. 1994), oestrogen (Pike et al. 1978) and $1,25(\mathrm{OH})_{2} \mathrm{D}_{3}$ itself (Dick et al. 1990; Jones et al. 1998). Serum $1,25(\mathrm{OH})_{2} \mathrm{D}_{3}$ levels decline with age (Armbrecht et al. 1982; Clemens et al. 1986). The decline in serum $1,25(\mathrm{OH})_{2} \mathrm{D}_{3}$ levels with ageing is thought to be one of the contributing factors in the pathogenesis of senile (type II) osteoporosis (Avioli et al. 1965; Gallagher et al. 1979). In particular, the age-related decrease in the circulating level of $1,25(\mathrm{OH})_{2} \mathrm{D}_{3}$ results in decreased vitamin D-dependent intestinal Ca absorption (Avioli et al. 1965; Gallagher et al. 1979), negative Ca balance, secondary hyperparathyroidism and bone loss (Malm et al. 1955; Armbrecht et al. 1980, 1982; Gray \& Gambert, 1982; Tsai et al. 1984; Wong et al. 1997, 2000).

The biosynthesis of $1,25(\mathrm{OH})_{2} \mathrm{D}_{3}$ is catalysed by 25 -hydroxyvitamin D 1- $\alpha$ hydroxylase (1-OHase; Henry \& Norman, 1974) while the degradation of $1,25(\mathrm{OH})_{2} \mathrm{D}_{3}$ is initiated by induction of 25-hydroxyvitamin $\quad \mathrm{D}_{3}$ 24-hydroxylase (24-OHase) activity (Akiyoshi-Shibata et al. 1994). These enzymes are regulated in a coordinate manner in different physiological conditions to control circulating levels of $1,25(\mathrm{OH})_{2} \mathrm{D}_{3}$. For example, PTH can increase serum $1,25(\mathrm{OH})_{2} \mathrm{D}_{3}$ levels by inducing $1-\mathrm{OH}$ ase activities and suppressing 24-OHase activities (Armbrecht et al. 1982). Similarly, $1,25(\mathrm{OH})_{2} \mathrm{D}_{3}$ can induce its own breakdown by strongly inducing 24-OHase mRNA expression and activities while suppressing 1OHase mRNA expression and activities simultaneously (Jones et al. 1998). Recently, renal vitamin D receptor (VDR) was also found to be actively involved in regulating renal metabolism of $1,25(\mathrm{OH})_{2} \mathrm{D}_{3}$ (Beckman \& DeLuca, 2002; Healy et al. 2003).

\footnotetext{
Abbreviations: $1,25(\mathrm{OH})_{2} \mathrm{D}_{3}, 1,25$-dihydroxyvitamin $\mathrm{D}$; 1-OHase, 25-hydroxyvitamin $\mathrm{D}_{3}$ 1- $\alpha$ hydroxylase; 24-OHase, 25-hydroxyvitamin $\mathrm{D}_{3}$ 24-hydroxylase; ALPD, adult rats fed LPD; AND, adult rats fed NPD; GAPDH, glyceraldehyde-3-phosphate dehydrogenase; LPD, low-phosphate diet; NPD, normal phosphate diet; PTH, parathyroid hormone; VDR, vitamin D receptor; YLPD, young rats fed LPD; YND, young rats fed NPD.

* Corresponding author: Dr Man-Sau Wong, fax +852 23649932, email bcmswong@ polyu.edu.hk

$\dagger$ These authors contributed equally to the studies.
} 
Down-regulation of renal VDR expression in response to hypocalcaemia can prevent $1,25(\mathrm{OH})_{2} \mathrm{D}_{3}$-mediated suppression of 1-OHase and induction of 24-OHase during dietary Ca restriction, thereby allowing a net increase in serum $1,25(\mathrm{OH})_{2} \mathrm{D}_{3}$ levels (Beckman \& DeLuca, 2002).

Dietary phosphate restriction is an important regulator of renal 1-OHase and 24-OHase activities and mRNA expression (Wu et al. 1996; Tenenhouse et al. 2001; Yoshida et al. 2001; Zhang et al. 2002). The effect of dietary phosphate restriction on vitamin D metabolism appears to be PTH-independent (Tanaka \& Deluca, 1975), and dependent upon growth hormone or insulin-like growth factor I (Gray, 1987; Halloran \& Spencer, 1988). In young rats, the adaptive response to low-phosphate diet (LPD) results in increased 1-OHase and decreased 24-OHase, leading to increase in serum $1,25(\mathrm{OH})_{2} \mathrm{D}_{3}$ and intestinal $\mathrm{P}$ transport (Hughes et al. 1975; Tanaka and Deluca 1975; Lee et al. 1979; Wu et al. 1996). However, in adult rats, the magnitudes of the increase in serum $1,25(\mathrm{OH})_{2} \mathrm{D}_{3}$ levels, intestinal $\mathrm{P}$ transport as well as net $\mathrm{P}$ absorption by LPD are reduced (Tanaka \& Deluca, 1975; Wong et al. 1997). Previous studies in our laboratory demonstrated that the reduced responses of serum $1,25(\mathrm{OH})_{2} \mathrm{D}_{3}$ levels to LPD in adult rats (4-6 months of age) was due to their inabilities to increase renal 1-OHase activity during LPD (Wong et al. 1997). These results are similar to those observed in studies using older rats (12-24 months of age) (Armbrecht et al. 1980, 1982, 1984, 1999, 2003), suggesting that the loss of renal 1-OHase to its stimuli occurs in rats as early as 4-6 months of age.

Our recent study further reported that the age-related changes in renal $1,25(\mathrm{OH})_{2} \mathrm{D}_{3}$ biosynthesis were due to the altered responses of adult rats to increase renal 1-OHase mRNA as well as protein expression within $5 \mathrm{~d}$ of LPD feeding (Lai et al. 2003). Since circulating levels of $1,25(\mathrm{OH})_{2} \mathrm{D}_{3}$ increase in adult rats in the absence of an increase in its biosynthesis during LPD treatment, we hypothesized that the mechanism involved in raising circulating $1,25(\mathrm{OH})_{2} \mathrm{D}_{3}$ in response to mineral deficiency alters with age. In the present study, we tested the hypothesis by studying the expression of genes involved in renal vitamin $\mathrm{D}$ metabolism (renal 1-OHase, 24-OHase and VDR) in young (1-month-old) and adult (6-month-old) rats in response to LPD.

\section{Materials and methods}

\section{Animals and diet study}

Male Sprague Dawley rats weighing 100-110g (young, 1 month old) and 462-560 g (adult, 6 months old) were first fed with a normal P diet (NPD; 0.6\% Ca, 0.65\% P; Teklad diet 98005 , Harlan Teklad, Madison, WI, USA) for $2 \mathrm{~d}$ and then switched to a low P diet (LPD; $0.6 \% \mathrm{Ca}, 0.1 \% \mathrm{P}$; Teklad diet 98004) ad libitum for $0-7 \mathrm{~d}$. All diets contained $0.055 \mu \mathrm{g} / \mathrm{g}$ vitamin $\mathrm{D}_{3}$ and their compositions are summarized in Table 1. Our preliminary experiment indicated that rats fed with either 2 or $10 \mathrm{~d}$ of NPD have similar serum $\mathrm{Ca}, \mathrm{P}$ and renal 1-OHase mRNA expression in both young and adult rats. Thus, $2 \mathrm{~d}$ of NPD feeding was chosen as the period of equilibration for all rat groups and rats fed $2 \mathrm{~d}$ of NPD (or $0 \mathrm{~d}$ of LPD) was chosen as the control group of our study. Rats were placed under ether anaesthesia and exsanguinated via the abdominal aorta. Rats were weighed before and after the diet treatment. Blood was collected for
Table 1. Composition of the normal phosphate diet (NPD) and the low-phosphate diet (LPD)

\begin{tabular}{|c|c|c|}
\hline & \multicolumn{2}{|c|}{ Composition (g/kg) } \\
\hline & NPD* & LPD† \\
\hline Casein & $110 \cdot 0$ & $110 \cdot 0$ \\
\hline $\begin{array}{l}\text { Egg-white solid, } \\
\text { spray-dried }\end{array}$ & $97 \cdot 9$ & $97 \cdot 9$ \\
\hline DL-Methionine & $3 \cdot 0$ & $3 \cdot 0$ \\
\hline Sucrose & $551 \cdot 1$ & $575 \cdot 7$ \\
\hline Corn starch & $100 \cdot 0$ & $100 \cdot 0$ \\
\hline Corn oil & $50 \cdot 0$ & $50 \cdot 0$ \\
\hline Cellulose & $20 \cdot 0$ & $20 \cdot 0$ \\
\hline $\begin{array}{l}\text { Vitamin mix, } \\
\text { Teklad }(40060)\end{array}$ & $10 \cdot 0$ & $10 \cdot 0$ \\
\hline $\begin{array}{l}\text { Potassium phosphate, } \\
\text { monobasic }\end{array}$ & $24 \cdot 6$ & - \\
\hline Calcium carbonate & $14 \cdot 7$ & $14 \cdot 7$ \\
\hline Potassium chloride & $5 \cdot 6$ & $5 \cdot 6$ \\
\hline Sodium bicarbonate & $4 \cdot 6$ & $4 \cdot 6$ \\
\hline Magnesium oxide & $3 \cdot 8$ & $3 \cdot 8$ \\
\hline Sodium chloride & $3 \cdot 7$ & $3 \cdot 7$ \\
\hline Sodium selenite & 0.50 & 0.5 \\
\hline Ferric citrate & 0.21 & $0 \cdot 21$ \\
\hline $\begin{array}{l}\text { Manganous } \\
\text { carbonate }\end{array}$ & 0.123 & 0.123 \\
\hline Zinc carbonate & 0.056 & 0.056 \\
\hline $\begin{array}{l}\text { Chromium potassium } \\
\text { sulphate }\end{array}$ & 0.0193 & 0.0193 \\
\hline Cupric carbonate & 0.011 & 0.011 \\
\hline Potassium iodate & 0.0004 & 0.0004 \\
\hline
\end{tabular}

${ }^{\star} \mathrm{Ca} 0.6 \%, \mathrm{P} 0.65 \%$ : cat. no. 98005 .

† Ca $0.6 \%$, P $0.1 \%$; cat. no. 98004 .

serum chemistry analysis. Serum phosphate and $\mathrm{Ca}$ were measured using colorimetric assay kits (Sigma, St. Louis, MO, USA) and serum $1,25(\mathrm{OH})_{2} \mathrm{D}_{3}$ levels were detected by a competitive assay kit (Immundiagnostik, Bensheim, Germany). The kidneys were removed, immediately frozen in liquid $\mathrm{N}$, and stored at $-80^{\circ} \mathrm{C}$ until use. In addition, young and adult rats were fed ad libitum with NPD or LPD for $10 \mathrm{~d}$ to determine the effect of prolonged LPD feeding on renal 1-OHase, 24-OHase and VDR mRNA expressions. All studies were conducted according to the principles and procedures contained in the most recent publication of the NIH Guide for the Care and Use of Laboratory Animals National Research Council (1996).

\section{RNA isolation and RT-PCR analysis of vitamin D-related genes}

The rat kidney was first homogenized with a Polytron. Total RNA was then isolated using Trizol reagent (Life Technologies, Grand Island, NY, USA) according to the manufacturer's instructions, and quantified by measuring the absorbance at $260 \mathrm{~nm}$. RT-PCR was employed to determine the expression of 1-OHase, 24OHase and VDR under dietary $\mathrm{P}$ restriction. Reverse transcription of mRNA was carried out using $5 \mu \mathrm{g}$ total RNA in a $20 \mu \mathrm{l}$ reaction volume containing $0.5 \mu \mathrm{g}$ oligo dT primer (Life Technologies), $200 \mathrm{U}^{\mathrm{TM}}$ RT (Life Technologies), $0.5 \mathrm{mM}$-dNTP, $10 \mathrm{mM}$-dithiothreitol, in the reaction buffer of $50 \mathrm{~mm}$-Tris- $\mathrm{HCl}(\mathrm{pH} 8 \cdot 3)$, $75 \mathrm{~mm}-\mathrm{KCl}, 3 \mathrm{mM}-\mathrm{MgCl}_{2}$. Total RNA was initially denatured at $70^{\circ} \mathrm{C}$ for $10 \mathrm{~min}$ and immediately chilled on ice. First-strand cDNA was synthesized after $50 \mathrm{~min}$ at $42^{\circ} \mathrm{C}$, followed by $70^{\circ} \mathrm{C}$ for $15 \mathrm{~min}$ to inactivate the RT. Two units of Rnase $\mathrm{H}$ were then added followed by incubation at $37^{\circ} \mathrm{C}$ for another $20 \mathrm{~min}$. 
The optimal PCR cycles for each gene product were determined to ensure the PCR products were obtained within the linear logarithmic phase of each amplification curve. Gene-specific primers used in the RT-PCR reaction of each gene are listed in Table 2. A housekeeping gene, glyceraldehyde-3-phosphate dehydrogenase (GAPDH) was used as internal control for mRNA normalization. The PCR condition is as follows $20 \mu \mathrm{l}$ : the $20 \mu \mathrm{l}$ cDNA reaction mixture was added to $100 \mu \mathrm{l}$ PCR mixture containing $0.1 \mu \mathrm{M}$ specific primers, $1 \times$ PCR reaction buffer, $200 \mu \mathrm{M}-\mathrm{dNTP}$ and 2.6 U DNA polymerase. Samples were first denatured at $95^{\circ} \mathrm{C}$ for $3 \mathrm{~min}$, amplified for optimized cycles and finally extended at $72^{\circ} \mathrm{C}$ for $5 \mathrm{~min}$. Each cycle consisted of $95^{\circ} \mathrm{C}$ for $1 \mathrm{~min}, 53^{\circ} \mathrm{C}$ for $30 \mathrm{~s}$ and $72^{\circ} \mathrm{C}$ for $3 \mathrm{~min}$. The PCR products were analysed by agarose gel electrophoresis. The intensity of the PCR products was quantified by Lumi-Image ${ }^{\mathrm{TM}} \mathrm{F} 1$ Workstation with the LumiAnalyst version 3.1 software (Roche Molecular Biochemicals, Mannheim, Germany). The band intensity captured from the Lumi-Image F1 Workstation was within the saturation limit. Gene expression was expressed as a ratio of the mRNA level of the enzyme component of interest to that of GAPDH.

To ensure conditions for RT-PCR can be used for semi-quantitative comparison of gene expression between different samples, cDNA template derived from the reverse transcription was serially diluted and amplified with the specified condition for each individual gene to test the linearity of the intensity of the PCR product. The linearity of the RT-PCR analysis was confirmed when the amount of the input cDNA was proportional to the signal intensity of the corresponding gene. All PCR products were sequence-verified to ensure the product representing the desired gene product. The PCR product bands were excised from the agarose gel and then purified using the gel extraction kit. The nucleotide sequences of the PCR products were determined by the dideoxynucleotide chain termination kit (Perkin Elmer, Foster, CA, USA) according to the manufacturer's protocol. The sequence read from the ABI 310 sequencer (Perkin Elmer) was subjected to the Blast search.

\section{Statistical analysis}

Data are reported as means with their standard errors. For the time-course experiment, significance of differences among group means were determined using one-way ANOVA followed by Tukey's method by GraphPad Prism version 4.02 (GraphPad Prism, San Diego, CA, USA) on serum $\mathrm{Ca}$, phosphate, $1,25(\mathrm{OH})_{2} \mathrm{D}_{3}, 1-\mathrm{OH}$ ase and 24-OHase mRNA expression levels. Group means of rats with different duration of LPD treatment were compared within their age group. Two-way ANOVA was also used to determine the interaction between diet treatment and age for both the time-course experiment as well as for the prolonged LPD treatment experiment on the serum $\mathrm{Ca}$, phosphate, $1,25(\mathrm{OH})_{2} \mathrm{D}_{3}, 1-\mathrm{OH}$ ase, 24-OHase and VDR mRNA expression levels. Group means of young rats fed NPD (YND) or LPD (YLPD) and adult rats fed NPD (AND) or LPD (ALPD) were compared. Student's $t$ test was used to compare the means of percentage change between young and adult rats in 1-OHase, 24-OHase and VDR mRNA expression. Group means differing by $P$ values of 0.05 and less are considered statistically significant.

\section{Results}

The effects of dietary $\mathrm{P}$ restriction on weight gain, serum $\mathrm{P}$ and $\mathrm{Ca}$ in young and adult rats are summarized in Table 3. Upon $1 \mathrm{~d}$ of LPD treatment, serum P decreased to 7.3 (SEM $0 \cdot 1$ ) $\mathrm{mg} / \mathrm{dl}$ $(P<0.01)$, v. $11.8(\mathrm{SEM} 0.5) \mathrm{mg} / \mathrm{dl}$ day 0 and remained low throughout the duration of LPD treatment $(P<0.001)$ in young rats. In contrast, serum $\mathrm{Ca}$ was not significantly increased in young rats on day 1 of LPD treatment from 9.9 (SEM 0.2) $\mathrm{mg} /$ dl for day 0 to 10.6 (SEM 0.4 ) $\mathrm{mg} / \mathrm{dl}$ for day 1) and remained unchanged for the duration of the study. In adult rats, serum $\mathrm{P}$ was reduced to $3.2($ SEM 0.6) $\mathrm{mg} / \mathrm{dl}(P<0.001)$ v. 6.3 (SEM 0.3) $\mathrm{mg} / \mathrm{dl}$ for day 0 upon $1 \mathrm{~d}$ of LPD treatment and remained low throughout the duration of LPD treatment. Serum Ca was unchanged in adult rats during the course of LPD treatment (NS, v. $10 \cdot 6(0 \cdot 6) \mathrm{mg} / \mathrm{dl}$ for day 0$)$

The responses of serum $1,25(\mathrm{OH})_{2} \mathrm{D}_{3}$ level to LPD treatment in both young and adult rats are shown in Fig. 1. In young rats, serum $1,25(\mathrm{OH})_{2} \mathrm{D}_{3}$ level was increased significantly to 5 -fold of the basal level by day 3 of LPD treatment and remained elevated until day 7 of LPD treatment $(P<0 \cdot 01, v$. day 0$)$. This elevation was also observed in adult rats fed 3-7d of LPD $(P<0.05, v$. day 0$)$; however, the extent of up-regulation was lower than that of the young rats $(2-3$-fold in adult rats $v$. 4-5-fold in young rats). In two-way ANOVA analysis, there is no interaction between diet treatment and age on the mean serum $\mathrm{P}$ and $\mathrm{Ca}$ concentrations of rats (serum $\mathrm{P}$ NS, $F$ 1.65, serum Ca NS, $F$ 0.14). However, significant interactions were observed between the effect of diet and age on the serum $1,25(\mathrm{OH})_{2} \mathrm{D}_{3}$ level $(P=0 \cdot 0011, F 5 \cdot 92)$.

The effects of LPD treatment on renal 1-OHase and 24-OHase mRNA expressions in young rats were determined by using RTPCR as shown in Fig. 2. Renal 1-OHase mRNA abundance in young rats began to increase on day 1 of LPD treatment $(P<0 \cdot 01, v$. day 0$)$, reached 3 -fold by day 3 of LPD treatment

Table 2. Primers used for vitamin D-related genes

\begin{tabular}{llc}
\hline Gene & Sequence & Accession no. \\
\hline 1-OHase & $\begin{array}{ll}\text { Forward primer: AAGGCAGCTGTCATCATCTCTC } \\
\text { Reverse primer: GATAGACCATGGCAGGAGATAG }\end{array}$ & AB001992 \\
24-OHase & Forward primer: CAGTATTCCTAAGACGGCGAAC & X59506 \\
VDR & Reverse primer: TCTATCTCCACACCCTGAAACC & \multirow{2}{*}{ J04147 } \\
GAPDH & Reverse primer: GGAGTGAATGCGTCTCTTCTGC & \multirow{2}{*}{00972} \\
& Forward primer: TGGCATCGTGGAAGGGCTCATG & \\
\hline
\end{tabular}

1-OHase, 25-hydroxyvitamin $D_{3}$ 1- $\alpha$ hydroxylase; 24-OHase, 25-hydroxyvitamin $D_{3}$ 24-hydroxylase; GAPDH, glyceraldehyde-3-phosphate dehydrogenase; VDR, vitamin $\mathrm{D}$ receptor. 
Table 3. Weight gain, serum calcium and phosphate levels in young and adult rats in response to low-phosphate diet (LPD) treatment $\dagger$

(Mean values with their standard errors of the mean for six rats per group)

\begin{tabular}{|c|c|c|c|c|c|c|}
\hline \multirow{2}{*}{$\begin{array}{l}\text { Day of LPD } \\
\text { treatment }\end{array}$} & \multicolumn{2}{|c|}{$\begin{array}{c}\text { Weight } \\
\text { gain/d (g/d) }\end{array}$} & \multicolumn{2}{|c|}{$\begin{array}{c}\text { Serum P } \\
\text { level }(\mathrm{mg} / \mathrm{dl})\end{array}$} & \multicolumn{2}{|c|}{$\begin{array}{c}\text { Serum Ca level } \\
(\mathrm{mg} / \mathrm{dl})\end{array}$} \\
\hline & Mean & SEM & Mean & SEM & Mean & SEM \\
\hline \multicolumn{7}{|l|}{ Young rats } \\
\hline 0 & $10 \cdot 3$ & 1.3 & $11 \cdot 8$ & 0.5 & 9.9 & 0.2 \\
\hline 1 & 9.0 & 0.6 & $7 \cdot 3$ & $0.1^{*}$ & $10 \cdot 6$ & 0.4 \\
\hline 3 & $6 \cdot 7$ & $1 \cdot 7$ & $7 \cdot 0$ & $0.3^{\star *}$ & $10 \cdot 4$ & 0.3 \\
\hline 5 & $5 \cdot 0$ & 0.5 & $5 \cdot 6$ & $0.5^{\star \star}$ & $10 \cdot 4$ & 0.1 \\
\hline 7 & $6 \cdot 3$ & 0.4 & $6 \cdot 8$ & $0 \cdot 2^{\star \star}$ & $10 \cdot 0$ & 0.9 \\
\hline \multicolumn{7}{|l|}{ Adult rats } \\
\hline 0 & $2 \cdot 0$ & $6 \cdot 2$ & $6 \cdot 3$ & 0.3 & $10 \cdot 6$ & 0.6 \\
\hline 1 & $4 \cdot 3$ & 0.9 & 3.2 & $0 \cdot 6^{\star \star}$ & 10.2 & 0.3 \\
\hline 3 & 1.8 & 0.8 & 3.8 & $0 \cdot 2^{\star \star}$ & 9.5 & 0.1 \\
\hline 5 & $4 \cdot 1$ & 1.6 & $4 \cdot 1$ & $0.5^{\star \star}$ & 9.9 & 0.1 \\
\hline 7 & -3.8 & $6 \cdot 3$ & 4.7 & $0 \cdot 3^{\star *}$ & 9.5 & 0.1 \\
\hline
\end{tabular}

Mean values were significantly different from those of rats at day 0 within the same age group, ${ }^{* *} P<0.01$ and ${ }^{* * *} P<0.001$.

† Young ( 1 month old) and adult ( 6 months old) male Sprague Dawley rats were fed with normal phosphate diet $(0.6 \% \mathrm{Ca}, 0.6 \% \mathrm{P})$ for $2 \mathrm{~d}$ and switched to LPD treatment $(0.6 \% \mathrm{Ca}, 0.1 \% \mathrm{P})$ for $0-7 \mathrm{~d}$

$(P<0 \cdot 001, v$. day 0$)$ and gradually returned to basal level by day 7 (Fig. 2(A, B)). The abundance of renal 24-OHase mRNA decreased by more than $90 \%$ upon $1 \mathrm{~d}$ of LPD treatment $(P<0.001, v$. day 0$)$ and remained suppressed throughout the duration of the study (Fig. 2(A, B)). The results showed that suppression of 24-OHase mRNA occurs more rapidly and to a greater extent than the increase in 1-OHase mRNA. The suppression of renal 24-OHase mRNA was prolonged while the abundance of renal 1-OHase mRNA returned to basal level at $7 \mathrm{~d}$ of LPD treatment (Fig. 2(B)).

In contrast to the responses of young rats to LPD, the abundance of renal 1-OHase mRNA did not increase in adult rats throughout the $7 \mathrm{~d}$ of LPD treatment (Fig. 3(A, B)). Nevertheless, the abundance of renal 24-OHase mRNA in adult rat decreased by $60 \%(P<0.001, v .90 \%$ in young rats) upon $3 \mathrm{~d}$ of LPD treatment $(P<0 \cdot 01, v$. day 0$)$ and remained suppressed throughout the duration of LPD treatment (Fig. 3(A, B)). In two-way ANOVA analysis, the effects of LPD alone $(P<0.0001, F 33.42,1$-OHase;

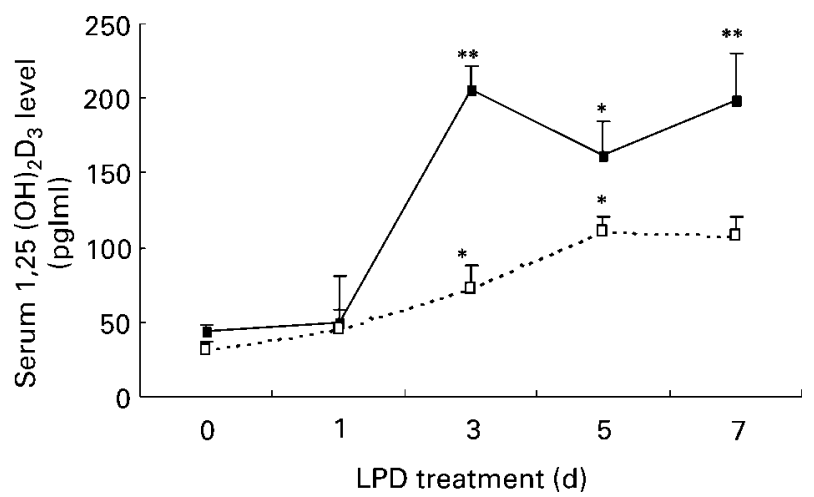

Fig. 1. Serum 1,25-dihydroxyvitamin $D\left(1,25(\mathrm{OH})_{2} \mathrm{D}_{3}\right)$ level in young and adult rats during low-phosphate diet (LPD) treatment. Both young (-) and adult $(\square)$ rats showed a significant increase in serum $1,25(\mathrm{OH})_{2} \mathrm{D}_{3}$ level by $3 \mathrm{~d}$ of LPD treatment. The level remained elevated till day 7 . Mean values were significantly different from those of rats at day 0 within the same age group, ${ }^{\star} P<0.05$ and ${ }^{* *} P<0.01$, with four rats per group.
$P<0.01, F 20.43,24-$ OHase $)$ and age alone $(P<0.0001, F$ 75.71, 1-OHase; $P<0.001, F 35.58,24-O H a s e)$ on 1-OHase and 24-OHase mRNA expressions were significant in rats. The interaction between LPD treatment and age was significant in mean 1OHase mRNA expressions $(P<0 \cdot 001, F 26.42)$, but not in mean 24-OHase mRNA expressions $(P>0.5, F$ 1.66). The latter suggests that the response of 1-OHase expression, but not 24OHase expression, to LPD is age-dependent.

To determine if the response of renal VDR mRNA expression to LPD treatment was altered by age, the abundance of VDR mRNA was determined in young and adult rats upon either 0 or $3 \mathrm{~d}$ of LPD treatment (Fig. 4). The abundance of renal VDR mRNA decreased upon $3 \mathrm{~d}$ of LPD treatment in both young (by $77 \%, P<0.001, v$. day 0 ) and adult (by $51 \%, P<0.05, v$. day 0 ) rats, while the magnitude of changes (\% decrease) in response to LPD treatment differed significantly in the two age groups (77 v. $51 \%, P<0.001$ ). In addition, our results indicate that the basal level of renal VDR mRNA in adult rats was significantly lower than that of the young rats (Fig. 4(B), $P<0.001$ ).

Our results indicate that adult rats did not increase renal 1OHase mRNA expression throughout $7 \mathrm{~d}$ of LPD treatment. To determine if longer duration of LPD would be needed for the induction of 1-OHase mRNA expression, both young and adult

(A)

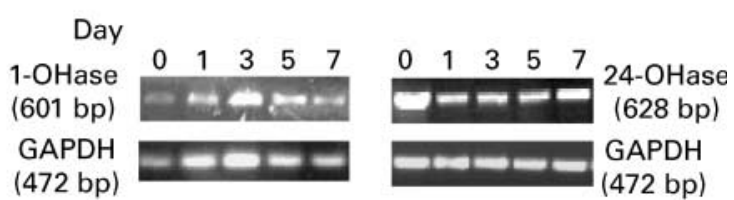

(B)

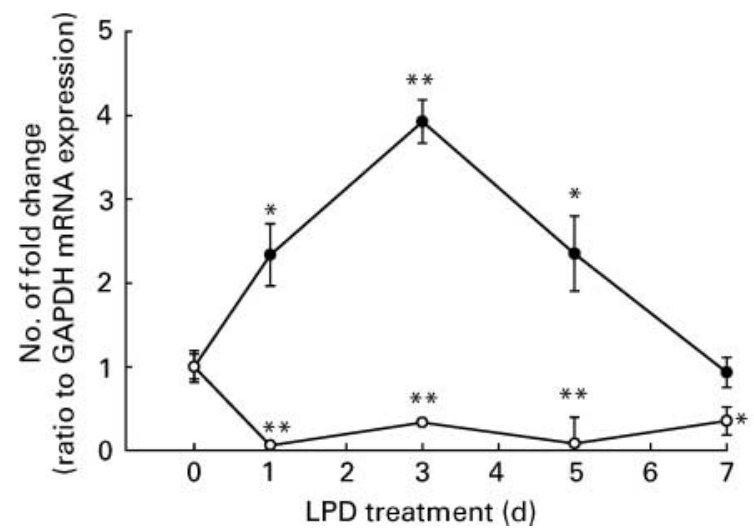

Fig. 2. Renal 25-hydroxyvitamin $D_{3}$ 24-hydroxylase (24-OHase) and 25hydroxyvitamin $D_{3} 1-\alpha$ hydroxylase (1-OHase) mRNA expression in young rats in response to low-phosphate diet (LPD). Young male Sprague Dawley rats (1 month old) were fed with normal phosphate diet $(0.6 \% \mathrm{Ca}$, $0.6 \% \mathrm{P})$ for $2 \mathrm{~d}$ and switched to LPD $(0.6 \% \mathrm{Ca}, 0.1 \% \mathrm{P})$ for $0-7 \mathrm{~d}$. Total RNA was extracted from kidney, and the conditions for RT-PCR are described on p. 300. (A), Time course of renal 1-OHase and 24-OHase mRNA in response to LPD treatment. (B), Graphical presentation of the coordinate expression of renal 1-OHase mRNA $(\bullet)$ and 24-OHase mRNA (o) relative to glyceraldehyde-3-phosphate dehydrogenase (GAPDH) mRNA. The expression of 1-OHase mRNA reached a maximum by day 3 significantly, but returned to the basal level by day 7 of LPD treatment. LPD treatment decreased the expression of 24-OHase mRNA significantly by day 1 and the effect was prolonged throughout the course of treatment. Data are expressed as means with their standard errors from three to four rats per group. For each group, statistical analysis was performed using one-way ANOVA followed by the use of Tukey's test as post-test analysis. Mean values were significantly different from those of rats at day 0 within the same age group, ${ }^{\star \star} P<0.01$ and ${ }^{* \star *} P<0.001$. 
(A)

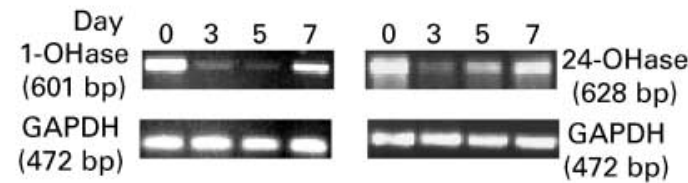

(B)

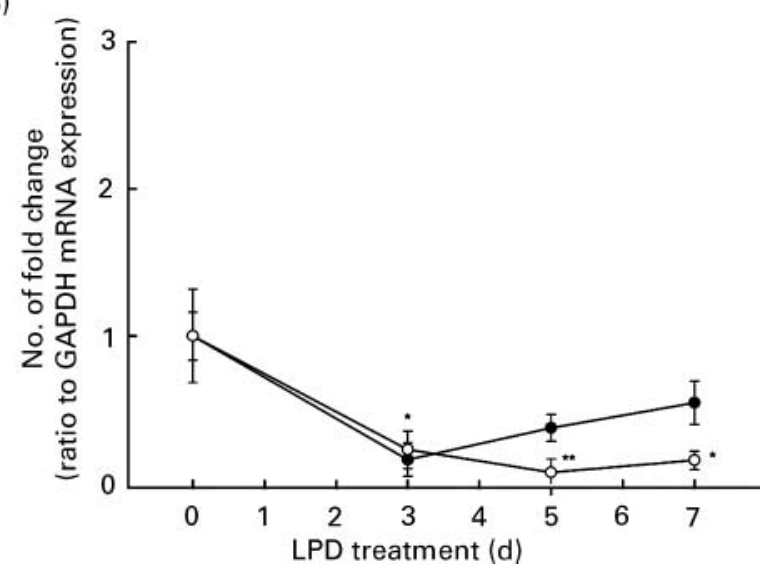

Fig. 3. Renal 25-hydroxyvitamin $D_{3}$ 24-hydroxylase (24-OHase) and 25hydroxyvitamin $D_{3} 1-\alpha$ hydroxylase (1-OHase) mRNA expression in adult rats in response to low-phosphate diet (LPD). Adult male Sprague Dawley rats (6 months old) were fed with normal phosphate diet $(0.6 \% \mathrm{Ca}, 0.6 \% \mathrm{P})$ for $2 \mathrm{~d}$ and switched to LPD $(0.6 \% \mathrm{Ca}, 0.1 \% \mathrm{P})$ for $0-7 \mathrm{~d}$. Total RNA was extracted from kidney and the conditions for RT-PCR are described in p. 300. (A), Time course of renal 1-OHase and 24-OHase mRNA on response to LPD treatment. (B), Graphical presentation of the coordinate expression of renal 1-OHase $(\bullet)$ and 24-OHase (o) mRNA relative to glyceraldehyde-3-phosphate dehydrogenase (GAPDH) mRNA. The mRNA expression of both enzymes was down-regulated by day 3 and their expressions remained low untill day 7 . Data are expressed as means with their standard errors from three to four rats per group. For each rat group, statistical analysis was performed using one-way ANOVA followed by the use of Tukey's test as post-test analysis. Mean values were significantly different from those of rats at day 0 within the same age group, ${ }^{\star \star} P<0.01$ and ${ }^{\star *} P<0.001$.

rats were fed with either NPD or LPD for $10 \mathrm{~d}$ and the expression levels of 1-OHase, 24-OHase and VDR mRNA were determined. The effects of diet treatment on weight change, serum $\mathrm{Ca}, \mathrm{P}$ and $1,25(\mathrm{OH})_{2} \mathrm{D}_{3}$ are summarized in Table 4. Serum $\mathrm{P}$ level decreased upon $10 \mathrm{~d}$ of LPD treatment in both age groups (YND $v$. YLPD10, $P<0.01$; AND $v$. ALPD10, $P<0 \cdot 01)$. The basal level of serum $\mathrm{P}$ was lower in adult rats (YND $v$. AND, $P<0 \cdot 001$ ). LPD treatment for $10 \mathrm{~d}$ increased serum $\mathrm{Ca}$ level significantly $(P<0 \cdot 001, v$. YND) in young rats but not in adult rats. Both age groups showed an elevation of serum $1,25(\mathrm{OH})_{2} \mathrm{D}_{3}$ level in response to LPD treatment (YND $v$. YLPD10, $P<0 \cdot 001$; AND $v$. ALPD10, $P<0.001$ ) (Table 4). As shown in Fig. 5, $10 \mathrm{~d}$ of LPD treatment increased renal 1-OHase mRNA expression in young (YND $v$. YLPD10, $P<0.001$ ) and adult rats (AND $v$. ALPD10, $P<0.05$ ), the magnitude of up-regulation in young rats was higher than that in adult rats $(125$ v. $80 \%, P<0.05)$. However, prolonged LPD treatment suppressed renal 24-OHase mRNA expression significantly in adult rats (AND $v$. ALPD10, $P<0.001$ ) but not in young rats (YND $v$. YLPD10); while the suppression of renal VDR mRNA expression by LPD treatment was significant only in young rats (YND $v$. YLPD10, $P<0.05$ ) but not in adult rats (AND v. ALPD10). In two-way ANOVA analysis, significant interactions between the effects of LPD and age were found for both renal 1-OHase and 24-OHase mRNA expressions, but not
(A)

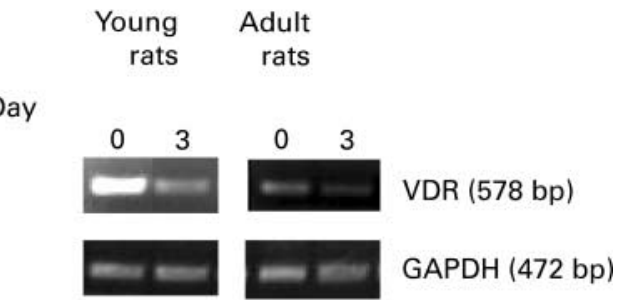

(B)

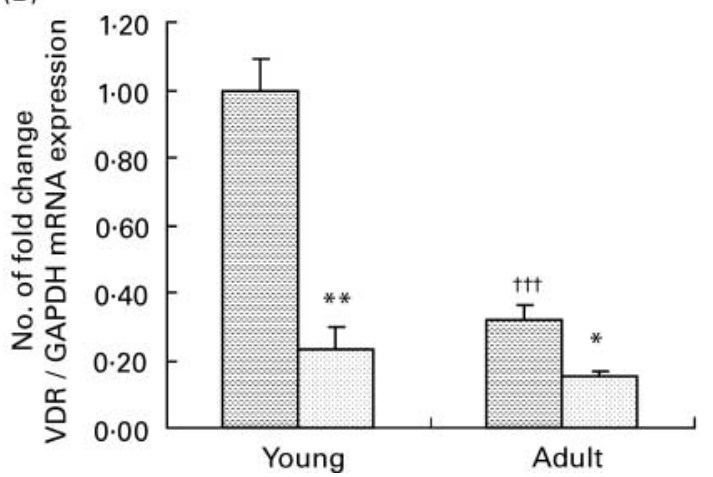

Fig. 4. Renal vitamin $D$ receptor (VDR) expression in response to $3 \mathrm{~d}$ of low-phosphate diet (LPD) treatment in young and adult rats. Young (1 month old) and adult (6 months old) male Sprague Dawley rats were fed with normal phosphate diet (NPD, $0.6 \% \mathrm{Ca}, 0.6 \% \mathrm{P})$ or LPD $(0.6 \% \mathrm{Ca}$, $0.1 \% \mathrm{P}$ ) for $3 \mathrm{~d}$. Total RNA was extracted from kidney and the conditions for RT-PCR are described on p. 300. (A), RT-PCR analysis of VDR mRNA expression in response to $3 \mathrm{~d}$ of LPD treatment in young and adult rats. (B), Graphical representation indicating the change of mRNA expression of VDR. Both age groups showed a significant decrease in VDR mRNA expression in response to LPD treatment. Basal expression of VDR was found to be higher in the younger group. Values represent means with their standard erros of three to four rats per group. Expression of VDR mRNA was normalized with that of glyceraldehyde-3-phosphate dehydrogenase (GAPDH) mRNA. Mean values were significantly different from those of rats fed with NPD within the same age group, ${ }^{\star} P<0.05$ and ${ }^{*} P<0.001$. Mean value was significantly different from that of young rats fed with NPD, $\dagger \dagger \dagger P<0.001$. ( $\square$ ) NPD; ( $\square$ ) LPD3

for renal VDR mRNA expression (1-OHase, $P<0 \cdot 05, F$ 4.97; 24-OHase, $P<0.05, F$ 4.95; VDR, $F$ 0.22).

\section{Discussion}

The increase in renal $1,25(\mathrm{OH})_{2} \mathrm{D}_{3}$ production during dietary $\mathrm{Ca}$ or phosphate restriction mediates vitamin D-dependent intestinal $\mathrm{Ca}$ and phosphate absorption. However, regulation of vitamin $\mathrm{D}$ metabolism changes with age (Armbrecht et al. 1980, 1982; Gray \& Gambert, 1982; Tsai et al. 1984; Friedlander et al. 1994; Wong et al. 1997, 2000). In older rats (12 months old), the ability to increase renal $1,25(\mathrm{OH})_{2} \mathrm{D}_{3}$ production and 1OHase mRNA expression in response to low-Ca diet feeding was reduced (Armbrecht et al. 1980, 1982, 1984, 2003). Previous studies in our laboratory demonstrated that the abilities to increase renal $1,25(\mathrm{OH})_{2} \mathrm{D}_{3}$ production in response to $\mathrm{PTH}$ (Friedlander et al. 1994), LPD (Wong et al. 1997) or low-Ca diet (Wong et al. 2000) were blunted in adult rats (4-6 months old). Our recent studies further reported that the lack of an increase in renal 1-OHase activities during $5 \mathrm{~d}$ of LPD was due to the inability of adult rats to increase its mRNA expression (Lai et al. 2003). In those studies, serum $1,25(\mathrm{OH})_{2} \mathrm{D}_{3}$ levels increased in response to a low $\mathrm{Ca}$ diet and LPD in adult rats 
without the increase in activities or mRNA expression of renal 1OHase, suggesting that other mechanisms are involved in raising serum $1,25(\mathrm{OH})_{2} \mathrm{D}_{3}$ levels.

The results of the present study support our hypothesis that the mechanisms involved in raising serum $1,25(\mathrm{OH})_{2} \mathrm{D}_{3}$ levels during LPD treatment alter with age. Our results clearly showed that young rats increased serum $1,25(\mathrm{OH})_{2} \mathrm{D}_{3}$ levels by increasing its biosynthesis via the induction of renal 1-OHase mRNA expression (Fig. 2) while decreasing its metabolic clearance via the suppression of renal 24-OHase (Fig. 2) and VDR (Fig. 4) mRNA expression during short-term LPD treatment. In contrast, adult rats increased serum $1,25(\mathrm{OH})_{2} \mathrm{D}_{3}$ levels by decreasing its metabolic clearance via the down-regulation of 24-OHase (Fig. 3) and VDR (Fig. 4) mRNA expression during short-term LPD treatment, while the induction of 1-OHase mRNA expression in adult rats only occurred upon a prolonged period of LPD treatment (Fig. 5).

The results of the present study suggest that down-regulation of metabolic clearance by 24-OHase is also an important mechanism for the up-regulation of circulating $1,25(\mathrm{OH})_{2} \mathrm{D}_{3}$ during LPD. As shown in Fig. 1, serum $1,25(\mathrm{OH})_{2} \mathrm{D}_{3}$ increased in response to LPD during which renal 1-OHase mRNA was not up-regulated in both young (day 7 of LPD treatment, Fig. 2) and adult rats (days 3-7 of LPD treatment, Fig. 3). Our previous study demonstrated that LPD increased 1-OHase mRNA and protein in young rats, but not adult rats, in a time-dependent manner in which an increase in renal 1-OHase mRNA on day 3 of LPD treatment was followed by an increase in renal 1OHase protein on days 3 and 5 of LPD treatment (Lai et al. 2003). In that particular study, we have shown that an increase in protein stability of 1-OHase is also a mechanism involved in up-regulation of the enzyme expression in young rats during LPD treatment (Lai et al. 2003). In the present study, the result clearly showed that the suppression of renal 24-OHase mRNA expression occurred on day 1 of LPD treatment and remained suppressed throughout the duration of LPD treatment in both young and adult rats. Thus, an increase in protein stability of renal 1-OHase protein as well as a decrease in metabolic clearance by 24-OHase might contribute to the discrepancies between observed serum $1,25(\mathrm{OH})_{2} \mathrm{D}_{3}$ as well as renal 1OHase mRNA in young rats fed LPD; while the suppression of metabolic clearance by $24-\mathrm{OHase}$ would likely be the major mechanism involved in up-regulation of serum $1,25(\mathrm{OH})_{2} \mathrm{D}_{3}$ in adult rats during LPD.

The results of our study also agree with the studies by Zhang et al. (2002) that the response of renal 24-OHase mRNA suppression to LPD precedes that of renal 1-OHase mRNA up-regulation. In their studies, they raised the possibility that a decrease in renal catabolism of $1,25(\mathrm{OH})_{2} \mathrm{D}_{3}$ together with an increase in its renal synthesis contribute to the increase in serum $1,25(\mathrm{OH})_{2} \mathrm{D}_{3}$ levels during phosphate restriction in young mice. Furthermore, the present study showed that basal 24-OHase mRNA expression increased with age (Fig. 5) and that the degree of suppression of 24-OHase mRNA during short-term LPD treatment decreased with age $(90 v$ v $60 \%)$. Thus, in addition to the age-related reduction in 1-OHase responses, these results showed that metabolic clearance of $1,25(\mathrm{OH})_{2} \mathrm{D}_{3}$ by $24-\mathrm{OHase}$ also increased with age. The latter provides another explanation for why adult animals have a much reduced response of serum $1,25(\mathrm{OH})_{2} \mathrm{D}_{3}$ to phosphate deficiency (Fig. 1).

A recent study showed that down-regulation of renal VDR expression was a mechanism involved in enhancement of renal 1-OHase mRNA expression as well as suppression of renal 24OHase mRNA expression. The decrease in functional VDR can reduce the inhibition of 1-OHase mRNA (Murayama et al. 1999) as well as the stimulation of 24-OHase mRNA (Roy \& Tenenhouse, 1996) normally induced by $1,25(\mathrm{OH})_{2} \mathrm{D}_{3}$. The present study showed that renal VDR mRNA abundance decreased in response to LPD treatment in both young and adult rats. Such reduction of VDR expression might facilitate the increase in 1-OHase mRNA expression and the decrease in 24-OHase mRNA expression in young rats during LPD treatment. The fact that LPD treatment could down-regulate renal VDR mRNA expression in adult rats, however, suggests that the inability of adult rats to increase renal 1-OHase mRNA expression by $3 \mathrm{~d}$ of LPD treatment is unlikely to be due to an age-related alteration of VDR regulation.

To determine if longer duration is required for the up-regulation of renal 1-OHase by a diet of $0.1 \% \mathrm{P}$ in adult rats, we extended the duration of LPD treatment from 7 to $10 \mathrm{~d}$. Our results clearly showed that renal 1-OHase mRNA expression could be induced by $10 \mathrm{~d}$ of LPD treatment in adult rats; however, the mechanism involved in its up-regulation by LPD might be different from their younger counterparts. In young rats, renal 1-OHase mRNA was up-regulated

Table 4. Weight gain, serum calcium, phosphate and 1,25-dihydroxyvitamin $D\left(1,25(\mathrm{OH})_{2} \mathrm{D}_{3}\right)$ levels in young and adult rats in response to $10 \mathrm{~d}$ of low-phosphate diet (LPD) treatment

(Mean values and their standard errors of the mean of eight rats per group)

\begin{tabular}{|c|c|c|c|c|c|c|c|c|}
\hline \multirow[b]{2}{*}{ Diet treatment } & \multicolumn{2}{|c|}{$\begin{array}{c}\text { Weight } \\
\text { change/d (g/d) }\end{array}$} & \multicolumn{2}{|c|}{$\begin{array}{c}\text { Serum P } \\
\text { level }(\mathrm{mg} / \mathrm{dl})\end{array}$} & \multicolumn{2}{|c|}{$\begin{array}{l}\text { Serum Ca level } \\
\qquad(\mathrm{mg} / \mathrm{dl})\end{array}$} & \multicolumn{2}{|c|}{$\begin{array}{l}\text { Serum } 1 \cdot 25(\mathrm{OH})_{2} \mathrm{D}_{3} \\
\quad \text { level }(\mathrm{pg} / \mathrm{ml})\end{array}$} \\
\hline & Mean & SEM & Mean & SEM & Mean & SEM & Mean & SEM \\
\hline \multicolumn{9}{|l|}{ Young rats } \\
\hline YND & $6 \cdot 66$ & 0.89 & 11.88 & 0.42 & $9 \cdot 70$ & 0.19 & 52.82 & $6 \cdot 86$ \\
\hline YLPD & $5 \cdot 80$ & 0.17 & $6 \cdot 37$ & $0.25^{*}$ & 11.64 & $0.46^{\star \star}$ & 209.63 & $15 \cdot 71^{\star \star}$ \\
\hline \multicolumn{9}{|l|}{ Adult rats } \\
\hline AND & $4 \cdot 16$ & $1 \cdot 18$ & $6 \cdot 31$ & $0.09^{\star}$ & $10 \cdot 36$ & 0.25 & 29.05 & $1 \cdot 39^{*}$ \\
\hline ALPD & 4.75 & $0.41^{* *}$ & 4.23 & $0 \cdot 13^{*}+\dagger \dagger$ & $10 \cdot 73$ & 0.06 & 90.99 & $7 \cdot 16^{\star \star}$ 十七† \\
\hline
\end{tabular}

Mean values with were significantly different from those of YND group, ${ }^{\star \star} P<0.01$ and ${ }^{\star \star \star} P<0.001$, Mean values were significantly different from those of AND group, $\dagger+\dagger P<0.001$.

$\ddagger$ Young (1 month old, YND and YLPD) and adult ( 6 months old, AND and ALPD) male Sprague Dawley rats were fed with either normal phosphate diet (NPD, $0.6 \% \mathrm{Ca}, 0.6 \% \mathrm{P})$ or LPD $(0.6 \% \mathrm{Ca}, 0.1 \% \mathrm{P})$ for $10 \mathrm{~d}$, respectively. 
during which serum P was reduced by LPD treatment (Table 3); whereas, in the case of adult rats, the induction did not occur at an earlier time even when serum $P$ was reduced. Hypophosphataemia alone is not sufficient for the induction of renal 1-OHase mRNA in adult rats. It is possible that the decrease in serum $\mathrm{P}$ per se is not the primary signal for triggering the up-regulation of renal 1OHase mRNA expression in both young and adult animals and that other signals that result from the secondary responses to hypophosphataemia are responsible for the 1-OHase regulation during LPD. In the case of adult rats, it is likely that a lag time is needed for generating the signals in response to hypophosphataemia

(A)

$$
\begin{gathered}
\text { Young } \\
\text { rats } \\
\text { rats }
\end{gathered}
$$

Day

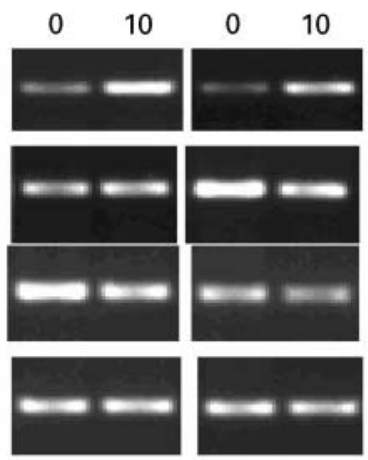

1-OHase (601 bp)

24-OHase (628 bp)

$\operatorname{VDR}(578 \mathrm{bp})$

GAPDH (472 bp)

(B)
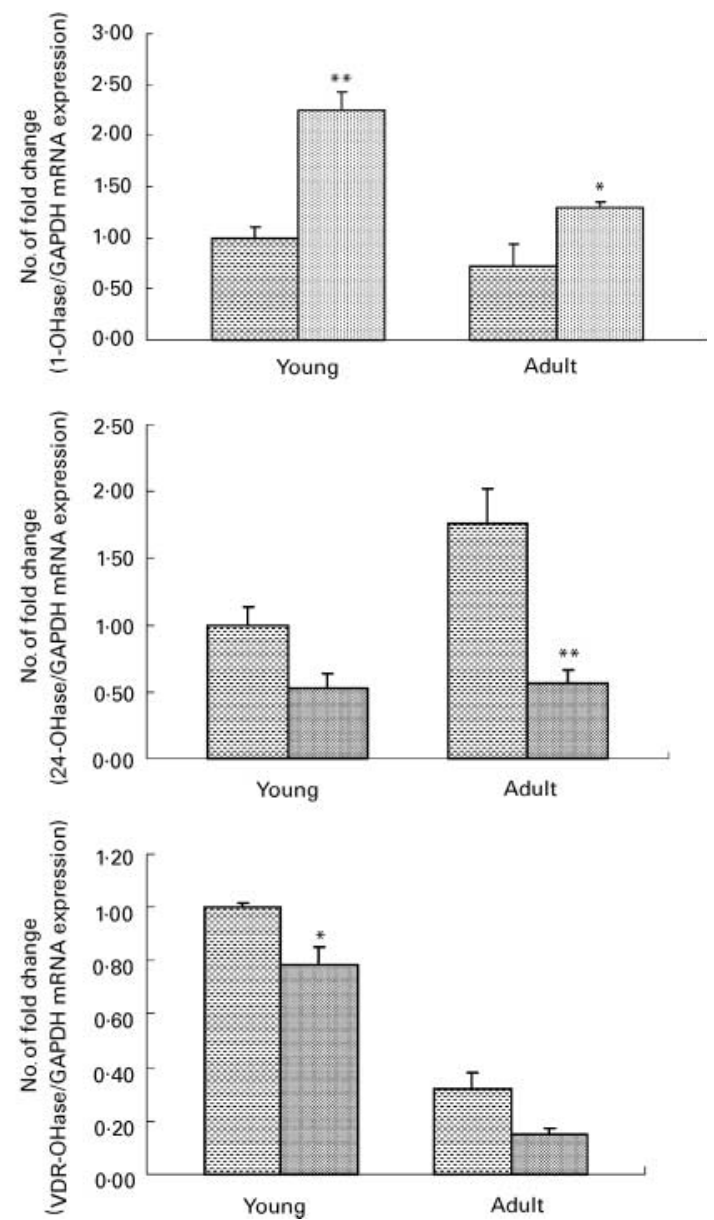

to induce up-regulation of renal 1-OHase mRNA during LPD treatment. Further studies will be needed to identify the mechanism involved in age-related alteration of renal 1-OHase mRNA expression during LPD treatment.

The mechanism whereby LPD treatment regulates vitamin D metabolism is poorly understood. It appears to be PTH-independent (Tanaka \& Deluca, 1975), and dependent upon growth hormone or insulin-like growth factor I (Gray, 1987; Halloran \& Spencer, 1988). Recently, two novel genes, PHEX and FGF-23, have been discovered to be involved in regulation of phosphate homeostasis (Takeda et al. 2004). The PHEX gene encodes an endopeptidase that breaks down FGF-23; while FGF-23 acts as a potent regulator to down-regulate renal phosphate transport and circulating $1,25(\mathrm{OH})_{2} \mathrm{D}_{3}$ levels (Shimada et al. 2004). The PHEX gene is mutated in X-linked hypophosphataemic rickets while a mutated form of FGF-23 is found to be accumulating in patients with autosomal dominant hypophosphataemic rickets. In both cases, the accumulation of FGF-23 leads to excessive P wasting and abnormal vitamin D metabolism. It will be of interest to determine if the expression of FGF-23 and PHEX alter with age and whether the age-related alteration in vitamin D metabolism is associated with changes in FGF-23 or PHEX expression.

In summary, the results in the present study support our hypothesis that the mechanism involved in increasing circulating $1,25(\mathrm{OH})_{2} \mathrm{D}_{3}$ levels alters with age. In young rats, LPD treatment induced renal 1-OHase mRNA expression, and decreased renal 24OHase and VDR mRNA expression, which results in a rapid increase in serum $1,25(\mathrm{OH})_{2} \mathrm{D}_{3}$ levels to meet the high demand for mineral for skeletal growth; whereas, in adult rats, LPD treatment initially increased serum $1,25(\mathrm{OH})_{2} \mathrm{D}_{3}$ levels by suppression of renal 24-OHase and VDR mRNA expression, followed by a delayed induction of renal 1-OHase mRNA expression. The overall decrease in responses of vitamin D metabolism in adult rats to LPD treatment might be part of a post-maturational process that signifies the decrease in skeletal requirement for mineral with age.

\section{Acknowledgements}

This work was supported by the Areas of Excellence Scheme established under the University Grants Committee of the Hong Kong Special Administrative Region, China (AOE/P-10/01), the

Fig. 5. Renal 25-hydroxyvitamin $D_{3} 1-\alpha$ hydroxylase (1-OHase), 25-hydroxyvitamin $D_{3}$ 24-hydroxylase (24-OHase) and vitamin D receptor (VDR) mRNA expressions in response to $10 \mathrm{~d}$ of low-phosphate diet (LPD) treatment in young and adult rats. Young ( 1 month old) and adult (6 months old) male Sprague Dawley rats were fed with either normal phosphate diet (NPD, $0.6 \% \mathrm{Ca}, 0.6 \% \mathrm{P})$ or LPD $(0.6 \% \mathrm{Ca}, 0.1 \% \mathrm{P})$ for $10 \mathrm{~d}$ (LPD 10$)$. (A), RTPCR analysis of 1-OHase, 24-OHase and VDR mRNA expression in response to $10 \mathrm{~d}$ of LPD treatment in young and adult rats. (B), Renal expression of 1-OHase (top panel), 24-OHase (middle panel) and VDR (bottom panel) mRNA upon $10 \mathrm{~d}$ of LPD treatment. LPD treatment for $10 \mathrm{~d}$ significantly increased 1-OHase mRNA expression in both young and adult rats. 24-OHase mRNA expression was significantly suppressed in adult rats in response to prolonged LPD treatment. Renal VDR mRNA expression was found in both age groups. However, significant suppression was only found in young rats in response to prolonged LPD treatment. Values represented means with their standard errors of eight animals per group and were analysed by two-way ANOVA. Expression of mRNA was normalized with glyceraldehyde-3-phosphate dehydrogenase (GAPDH) mRNA. Mean values were found to be significantly different from those of rats fed NPD within the same age group, ${ }^{*} P<0.05$ and ${ }^{* *} P<0.001$, (固) NPD; (图) LPD 10. 
Area of Strategic Development Grant of the Hong Kong Polytechnic University (A014) and the central allocation grant from the Research Committee of the Hong Kong Polytechnic University (GT849, GT067, APC80, GW030 and GV884).

\section{References}

Akiyoshi-Shibata M, Sakaki T, Ohyama Y, Noshiro M, Okuda K \& Yabusaki Y (1994) Further oxidation of hydroxycalcidiol by calcidiol 24-hydroxylase. Eur J Biochem 224, 335-343.

Armbrecht HJ, Forte LR \& Halloran BP (1984) Effect of age and dietary calcium on renal 25(OH)D metabolism, serum 1,25(OH)2D, and PTH. Am J Physiol 246, E266-E270.

Armbrecht HJ, Boltz MA \& Hodam TL (2003) PTH increases renal $25(\mathrm{OH}) \mathrm{D}_{3}-1 \alpha$-hydroxylase $(\mathrm{CYP} 1 \alpha)$ mRNA but not renal $1,25(\mathrm{OH})_{2} \mathrm{D}_{3}$ production in adult rats. Am J Physiol Renal Physiol 284, F1032-F1036.

Armbrecht HJ, Hodam TL, Boltz MA \& Kumar VB (1999) Capacity of a low calcium diet to induce the renal vitamin D $1 \alpha$-hydroxylase is decreased in adult rats. Biochem Biophys Res Commun 255, 731-734.

Armbrecht HJ, Wongsurawat N, Zenser TV \& Davis BB (1982) Differential effects of parathyroid hormone on the renal 1,25-dihydroxyvitamin $\mathrm{D}_{3}$ and 24,25-dihydroxyvitamin $\mathrm{D}_{3}$ production of young and adult rats. Endocrinology 111, 1339-1344.

Armbrecht HJ, Zenser TV \& Davis BB (1980) Effect of age on the conversion of 25-hydroxyvitamin D3 to 1,25-dihydroxyvitamin D3 by kidney of rat. $J$ Clin Invest 66, 1118-1123.

Avioli LV, McDonald JE \& Lee SW (1965) The influence of age on the intestinal absorption of ${ }^{47} \mathrm{Ca}$ in women and its relation to ${ }^{47} \mathrm{Ca}$ absorption in postmenopausal women. J Clin Invest 44, 1960-1967.

Beckman MJ \& DeLuca HK (2002) Regulation of renal vitamin D receptor is an important determinant of 1alpha,25-dihydroxyvitamin $\mathrm{D}(3)$ levels in vivo. Arch Biochem Biophys 401, 44-52.

Clemens TL, Zhou XY, Myles M, Endres D \& Lindsay R (1986) Serum vitamin D2 and vitamin D3 metabolite concentrations and absorption of vitamin D2 in elderly subjects. J Clin Endocrinol Metab 63, 656-660.

Condamine L, Vrtovsnik F, Friedlander G \& Garabedian M (1994) Local action of phosphate depletion and insulin-like growth factor 1 on in vitro production of 1,25-dihydroxyvitamin D by cultured mammalian kidney cells. J Clin Invest 94, 1673-1679.

Dick IM, Retallack R \& Prince RL (1990) Rapid nongenomic inhibition of renal 25-hydroxyvitamin D3 1-hydroxylase by 1,25-dihydroxyvitamin D3. Am J Physiol 259, E272-E277.

Favus MJ \& Tembe V (1992) The use of pharmacologic agents to study mechanisms of intestinal calcium transport. J Nutr 122, Suppl., $683-686$.

Friedlander J, Janulis M, Tembe V, Ro HK, Wong MS \& Favus MJ (1994) Loss of parathyroid hormone stimulated $1,25(\mathrm{OH})_{2} \mathrm{D}_{3}$ production in aging does not involve protein kinase A or protein kinase $\mathrm{C}$ pathways. J Bone Miner Res 9, 339-345.

Gallagher JC, Riggs BL, Eisman JA, Hamstra A, Arnaud SB \& Deluca HF (1979) Intestinal calcium absorption and serum vitamin D metabolites in normal subjects and osteoporotic patients. J Clin Invest 64, 729-736.

Garabedian M, Holick MF, DeLuca HF \& Boyle BL (1972) Control of 25hydroxycholecalciferol metabolism by parathyroid glands. Proc Natl Acad Sci USA 69, 1673-1676.

Gray RW (1987) Evidence that somatomedins mediate the effect of hypophosphatemia to increase serum 1,25-dihydroxyvitamin $\mathrm{D}_{3}$ level in rats. Endocrinology 121, 504-512.

Gray RW \& Gambert SR (1982) Effect of age on plasma $1,25(\mathrm{OH})_{2}$ vitamin D in the rat. Age 5, 54-56.

Gray RW \& Garthwaite TL (1985) Activation of renal 1,25dihydroxyvitamin D3 synthesis by phosphate deprivation: evidence for a role for growth hormone. Endocrinology 116, 189-193.

Healy KD, Zella JB, Prahl JM \& DeLuca HF (2003) Regulation of the murine renal vitamin D receptor by 1,25-dihydroxyvitamin D3 and calcium. Proc Natl Acad Sci USA 100, 9733-9737.

Halloran BP \& Spencer EM (1988) Dietary phosphorus and 1,25-dihydroxyvitamin D metabolism: influence of insulin-like growth factor I. Endocrinology 123, 1225-1229.

Henry HL \& Norman AW (1974) Studies on calciferol metabolism. IX. Renal 25-hydroxy-vitamin D3-1 hydroxylase. Involvement of cytochrome P-450 and other properties. J Biol Chem 249, 7529-7535.

Hughes MR, Brumbaugh PF, Haussler MR, Wergedal JE \& Baylink DJ (1975) Regulation of serum 1,25-dihydroxyvitamin $\mathrm{D}_{3}$ by calcium and phosphate in the rat. Science 190, 578-579.

Jones G, Strugnell SA \& DeLuca HF (1998) Current understanding of the molecular actions of vitamin D. Physiol Rev 78, 1193-1231.

Lai WP, Chau TS, Cheung PY, Chen WF, Lo SCL, Favus MJ \& Wong MS (2003) Adaptive responses of 25-hydroxyvitamin $\mathrm{D}_{3}$ 1-alpha hydroxylase expression to dietary phosphate restriction in young and adult rats. Biochim Biophys Acta 1639, 34-42.

Lee DBN, Brautbar N, Walling MW, Silis V, Oburn CJW \& Kleeman CR (1979) Effect of phosphorus depletion on intestinal calcium and phosphorus absorption. Am J Physiol 236, E451-E457.

Malm OJ, Nickolaysen R \& Skjelkvale L (1955) Calcium metabolism in old age as related to ageing of the skeleton. In Ageing - General Aspects, Ciba Foundation Colloquia on Ageing, pp. 109-125 [GEW Wolstenholme and MR Cameron, editors]. Boston: Little, Brown.

Murayama A, Takeyama K, Kitanaka S, Kodera Y, Kawaguchi Y, Hosoya $\mathrm{T} \&$ Kato $\mathrm{S}$ (1999) Positive and negative regulation of the renal 25hydroxyvitamin $\mathrm{D}_{3} 1 \alpha$-hydroxylase gene by parathyroid hormone, calcitonin, and $1,25(\mathrm{OH})_{2} \mathrm{D}_{3}$ in intact animals. Endocrinology 140, 2224-2231.

National Research Council (1996) Guide for the care and use of laboratory animals. National Academy Press, Washington D.C.

Nesbitt T \& Drezner MK (1993) Insulin-like growth factor-I regulation of renal 25-hydroxyvitamin D-1-hydroxylase activity. Endocrinology 132, $133-138$.

Pike JW, Spanos E, Colston KW, Macintyre I \& Haussler MR (1978) Influence of estrogen on renal vitamin D hydroxylases and serum 1alpha,25-(OH)2D3 in chicks. Am J Physiol 235, E338-E343.

Roy S \& Tenenhouse HS (1996) Transcriptional regulation and renal localization of 1,25-dihydroxyvitamin $\mathrm{D}_{3}$-24-hydroxylase gene expression: effects of the Hyp mutation and 1,25-dihydroxyvitamin $\mathrm{D}_{3}$. Endocrinology 137, 2938-2946.

Shimada T, Hasegawa H, Yamazaki Y, Muto T, Hino R, Takeuchi Y, Fujita T, Nakahara K, Fukumoto S \& Yamashita T (2004) FGF-23 is a potent regulator of vitamin $\mathrm{D}$ metabolism and phosphate homeostasis. J Bone Miner Res 19, 429-435.

Spanos E, Barrett D, Maclntyre I, Pike JW, Safilian WF \& Haussler MR (1978) Effect of growth hormone on vitamin D metabolism. Nature 273, 246-247.

Tanaka Y \& Deluca HF (1975) The control of 25-hydroxyvitamin D metabolism by inorganic phosphorus. Arch Biochem Biophys 154, 566-574.

Takeda E, Yamamoto H, Nashiki K, Sato T, Arai H \& Taketani Y (2004) Inorganic phosphate homeostasis and the role of dietary phosphorus. $J$ Cell Mol Med 8, 191-200.

Tenenhouse HS, Martel J, Gauthier C, Zhang MYH \& Portale AA (2001) Renal expression of the sodium/phosphate cotransporter gene, Npt2, is not required for regulation of renal 1a-hydroxylase by phosphate. Endocrinology 142, 1124-1129.

Tsai KS, Heath HIII, Kumar R \& Riggs BL (1984) Impaired vitamin D metabolism with aging in women. Possible role in pathogenesis of senile osteoporosis. J Clin Invest 73, 1668-1672.

Wilz DR, Gray RW, Dominguez JH \& Lemann J Jr (1979) Plasma 1,25(OH)2-vitamin D concentrations and net intestinal calcium, phosphate, and magnesium absorption in humans. Am J Clin Nutr 10, 2052-2060.

Wong MS, Sriussadaporn S, Tembe VA \& Favus MJ (1997) Insulin-like growth factor I increases renal $1,25(\mathrm{OH})_{2} \mathrm{D}_{3}$ biosynthesis during low$\mathrm{P}$ diet in adult rats. Am J Physiol 272, F698-F703. 
Wong MS, Tembe VA \& Favus MJ (2000) Insulin-like growth factor-I stimulates renal 1,25-dihydroxycholecalciferol synthesis in old rats fed a low calcium diet. J Nutr 130, 1147-1152.

Wu S, Finch J, Zhong M, Slatopolsky E, Grieff M \& Brown AJ (1996) Expression of the renal 25-hydroxyvitamin D-24-hydroxylase gene: regulation by dietary phosphate. Am J Physiol 271, F203-F208.

Yoshida T, Toshida N, Monkawa T, Hayashi M \& Saruta T (2001) Dietary phosphorus deprivation induces 25 -hydroxyvitamin $\mathrm{D}_{3} 1 \alpha$-hydroxylase gene expression. Endocrinology 142, 1720-1726.

Zhang MYH, Wang X, Wang JT, Compagnone NA, Mellon SH, Olson JL, Tenenhouse HS, Miller WL \& Portale AA (2002) Dietary phosphorus transcriptionally regulates 25-hydroxyvitamin D- $\alpha$ hydroxylase gene expression in the proximal renal tubule. Endocrinology 143, 587-595. 